\title{
Analysis of Full-Process Career Planning in Higher Education from the Perspective of Talents Training
}

\author{
Jia LIU \& Cheng CHENG \& Hong ZHANG \\ Polytechnic College, Hebei University of Science and Technology, Shijiazhuang, Hebei, China \\ Xuqian ZUO \\ Hebei Chemical \& Pharmaceutical College, Shijiazhuang, China
}

\begin{abstract}
This paper discusses some issues concerning career planning of college students, from the perspective of talents development. Some life-time education theories, quality-oriented educational systems are analyzed. Some proposals are offered to college students to build up full-process career planning systems for more employment opportunities.
\end{abstract}

KEYWORD: higher education; career planning; educational pattern; talents training

Career planning training can improve college students' ability to pursue their careers. The results of the training depend on whether comprehensive, systemic, target-oriented education is offered, thus changing students' lives differently. Those who can plan their careers and lives are likely to succeed. However, career development in China has been hindered due to changes of economic structures and flexible styles of employment. More and more college graduates are faced with great stress. Therefore, it is necessary to offer them proper employment guidance, so that they may know more about themselves, the world, and their future jobs. If they have right attitudes towards their choices of jobs, starting up their own businesses, they will be more competitive in the job market. Accordingly, it is important to build up a system of full-process career planning.

\section{DEFINITION OF CAREER PLANNING}

Career planning refers to the integration of individuals and society. That is, college students should first analyze and balance their interests, hobbies, abilities and characters, and then decide their future careers to accord with society. Finally, they should make a detailed plan of their efforts. In this way, students can know more about themselves and the environments; they will build up scientific outlook, values of life and development; they will employ appropriate approaches and measures, overcome all the difficulties and obstacles in their career planning. That is the aim of career planning.

\section{SOME PROBLEMS IN CAREER PLANNING}

From the perspectives of students, the problems lie in the following. On the one hand, they can't evaluate themselves properly to set up their career goals. For example, they are either too self-confident or underestimate their own capabilities. On the other hand, they can't evaluate their job opportunities properly. For instance, they may be uncertain about their choices, because they are affected by some external factors; they can't match themselves with the professional requirements.

As far as colleges and universities are concerned, their focus is on the graduates. Some more efforts should be put into career planning. First, school authorities and employment departments should coordinate to adapt to the changes in the job markets. Second, more resources supports are needed. In some universities, career guidance is in the charge of students' affairs departments. Some proposals from the guidance centers are sometimes ignored. Third, career guidance departments should act as coordinators rather than administers.

\section{THE RECONSTRUCTION OF FULL- PROCESS-CAREER-PLANNING EDUCATION}

\subsection{Principles of full-process-career-planning education}

\subsubsection{Individual and society should be the main concerns in the education.}

Each person may choose his own career, so career education should be centered around students' 
interest and character. It is vital to show respect for his character, to target at developing his personality, to place emphasis on his individualism. The goal of career planning lies in helping students know about his individualism and ego to set up feasible plans. On orientation, guidance is given to freshmen to make a specific plan and to realize their final goals. In terms of society students should work hard in order to become qualified members of the society.

\subsubsection{Principles of combining theory with practice}

Theoretical knowledge and critical thinking will guarantee students to broaden their horizons. Participation in various social activities will ensure them to learn to solve possible problems ahead in the future. Current employment situations and policies will offer them the chance to commit to the national reforms, and effective guidance to choose their careers.

\subsection{Guidance of full-process career planning}

The guide to career planning covers academic performance, choice of careers and after-graduation career guidance. It is quite different from the traditional guidance, because more things are added. For example, career planning, guide to employment, business start-ups, mental health, etc.

Full-process career training should be carried out step by step throughout the entire college life, each stage being for different semester and grade. The training process is for different students with different goals, psychological behaviors and characters. For freshmen, they should learn to think critically to hold correct attitudes towards their academic achievement. For sophomores, they should get career-oriented education to prepare their interest for future careers. For juniors, they should do programs of career guidance, because they will concentrate on their specialties and have clear goals. For seniors, they will be guided in field trips, taking post-graduation exams, and starting up their own businesses.

\subsection{The construction of full-process career planning}

\subsubsection{Tutoring courses for career training}

In China, some theories of careering planning are still new to both students and teachers. Career planning courses have been introduced and still at early stage of development. So it is necessary to set up a systematic curriculum for college students and universities. The programs should start with first year students, so that they may be well prepared for their future careers. For the fourth year students, they should be given enough guidance of career planning so that they may get their ideal jobs.

\subsubsection{Teacher development in career planning}

Teacher development is very important for career planning education, because it is closely related to the students' choice of their ideal future careers. Career training teachers can be developed by hiring full-time, part-time and temporary teachers, which establishes a career training team of college teachers contributing to the development of career training.

\subsubsection{Personalized career training system}

Because different students have different knowledge of themselves, choices of careers, plans of careers, career training should stick to principle of combining general guidance with personalized training. According to the differences between their personalities and majors, Internet evaluations can be used to train students, provide consultancy and track service, create profiles, which helps students plan their careers. Schools should guide students to make their long-term career plans, optimize the career training system, improve the services.

\subsubsection{Development of career planning evaluation system}

Self-cognition is a subjectively complex problem. Students often lack of scientific grounds for knowing their interests, personalities and abilities. So self-cognition analysis can be done by the research of psychological evaluations, by scientific research of students' self-abilities, interests and personalities. Talents evaluation is a research of abilities and personalities by psychological tests and situation simulation, which is based on modern psychology and management. If the evaluations are done scientifically, students can strengthen their self-awareness and have a clear idea of their future careers.

\subsubsection{Setup of career counseling platform}

In order to help students choose their jobs correctly, colleges should provide more career information positively and help students exactly get more firsthand information about the development of society. Knowing about external working environment is important for students finding proper jobs . So colleges can provide students with more channels for employment by newspapers, Internet, show windows, job fairs, lectures, forums and by assistance of agencies, alumni associations, society organizations, and internship institutes.

Career planning is a new field with a mature theoretical system, which will be the indispensable part of higher education. Career planning education is a good way to promote their competitiveness and tackle their employment problems. Colleges should lead students to make career planning positively , build career training mode, offer courses of career 
planning, perfect career training system, improve services, set up educational mode of career planning throughout the entire college life and help students make a long-term plan of future career.

\section{REFERENCES}

[1] Crites; Hartung,et al, Education \& School Psychology, British Journal of Educational Psychology, Volume 76,Issue 1 pp. $141-153,5,2006$.

[2] D. Blusteln. The interface of work and relationships: critical knowledge for $21^{\text {st }}$ century Psycholop, The Counseling Psychologist.2001.
[3] S. Norman Feingold. Perspectives on career guidance: An administrator's view. Peabody Journal of Education, 2009, 52(1):5-13.

[4] David Wadley. Good development, better planning: The nexus revisited. Planning Practice and Research, 2004, 19(2):173-193.

[5] The new Political economy of globalisation: Vol. 1-2/ed. by Richard Higgott and Anthony Payne-Cheltenham; Northampton, MA.: Edward Elgar, 2000.

[6] HollandJL. Making Voeational Choiees: Athcory of Voeational Personalities and Work Enviroments, 2nded Eglewood Cliffs. NJ prentice Hall:985 